\title{
Economic policy towards the challenges of the COVID- 19 pandemic in selected European Union countries
}

\author{
Martyna Żak, Jakub Garncarz
}

\section{A B S T R A C T}

Objective: The aim of the article was to investigate the impact of various policies to reduce the spread of epidemics on the functioning of key areas of the economy.

Research Design \& Methods: The study was constructed as an analysis of the development of epidemics in selected countries over time. Data was collected on the development of the epidemic, adopted models of fighting the epidemic, both in the area of restrictions and restrictions, as well as economic support measures. In order to find an answer to the question of which model of fighting the epidemic is the most effective, countries that used different methods of fighting were compared. The study used a quantitative method to present data on the scale of the epidemic crisis and also to present the economic crisis: the size of the unemployment rate, production volume in industry, and retail trade in the countries studied. A partial literature query, comparative method and case study method were also used.

Findings: The study showed no clear links between parents counteracting the spread of the epidemic, accessible to infected and diseased people, and the economic economy. The observations presented in the article may constitute an introduction to further research on the policies applied during the epidemic. in order to present clear correlations and benchmark models, it would be necessary to obtain daily data for the individual indicators and conduct research over a longer period.

Contribution \& Value Added: This article as a whole compiles and analyses what actions were taken by national governments to limit the spread of the coronavirus epidemic. The article also describes how the economies of these countries responded to the actions taken.

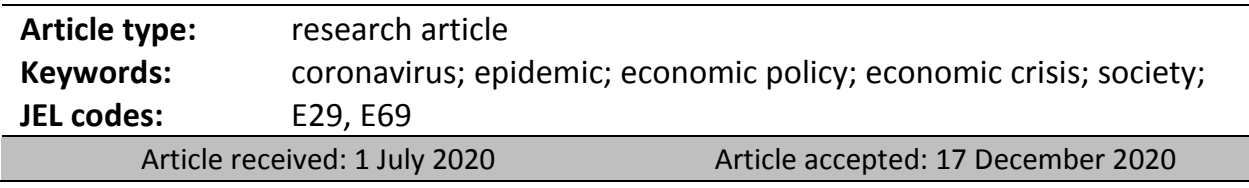

\section{Suggested citation:}

Żak, M., \& Garncarz, J. (2020). Coronavirus epidemic management and economic policy towards the challenges associated with the COVID-19 epidemic in selected European Union countries. International Entrepreneurship Review (previously published as International Entrepreneurship / Przedsiębiorczość Międzynarodowa), 6(4), 21-34. https://doi.org/10.15678/IER.2020.0604.02 


\section{INTRODUCTION}

Crisis situations are always for politicians and economists a kind of verification of the accuracy of their policies or implemented economic models. Such a test can be called the coronavirus epidemic and the socio-economic crisis that followed. The specificity of the pandemic crisis is the difficulty in predicting the development of events that are developing extremely dynamically. The article aims to present the development of the epidemic in selected European Union countries and to present economic solutions proposed by governments. Five European Union countries were selected for the study: Germany, Poland, Sweden, Italy and the Czech Republic. The selection of countries was dictated by different ways of fighting the spreading coronavirus epidemic and the different course of the COVID-19 epidemic in these countries.

By June 27, 2020, 9919525 cases of infection were diagnosed worldwide, of which 497255 people had died (WHO, 2020). In addition to the threat to life and health, the virus also disrupted economic relations between countries, which were forced to limit the transmission of the virus by closing many workplaces.

The study used a quantitative method to present data on the scale of the epidemic crisis: data on the number of infections and deaths caused by COVID-19, as well as to present the economic crisis: the size of the unemployment rate, the volume of production in industry, and retail trade in the countries studied. A partial literature query, comparative method and case study method were used to present ways to combat the epidemic and economic crisis in selected EU countries.

The introduction to the article presents the background to the article and the purpose of the research paper. The specificity of the crisis mentioned in the article was also suggested - the economic crisis caused by the epidemic. It then reviews the literature on the development of COVID-19 around the world, the elements causing the economic crisis, and presents the theoretical framework of selected policies to prevent an epidemic and economic crisis. By reviewing the literature, the current findings on the effects of actions taken by selected countries in the face of the pandemic in 2020 have been collected. Attention was paid to the effects that the crisis may bring to countries, households, workers and enterprises.

The next chapter on research methods shows the methods used in the research. The research that was carried out is presented below. Quantitative data are presented to determine the course of the epidemic in selected countries, including in Poland, Germany, the Czech Republic, Sweden and Italy, the choice of states was dictated by a different development of the epidemic and other methods of struggle adopted by state governments. The number of the infected and those who died as a result of coronavirus infection in the period March - July 2020 was presented. Actions taken both in the sphere of health services and in the area of the economy are described. Changes in the employment rate, production volume and economic activity of entities in the analysed countries were shown in order to check the impact of the epidemic on the economies. The conclusions of the authors of the article on the obtained results are presented in the summary. 


\section{LITERATURE REVIEW}

COVID-19 is an acute respiratory contagious disease observed for the first time in December 2019 in the Chinese city of Wuhan. Typical symptoms of the disease are fever, dry cough, fatigue and shallow breathing. On February 11, 2020, WHO officially called the disease COVID-19. The disease is characterized by low mortality at the level of $2-5 \%$, and transmission occurs by droplet route as a result of coughing or sneezing (Wu \& McGoogan, 2020). A characteristic feature of the COVID-19 virus is that it also spreads through surfaces or objects with which it has been infected (Li \& De Clerq, 2020). Unlike influenza, the COVID-19 virus takes about $15 \%$ of those infected to be acute and $5 \%$ to critical, which can result in death 2 to 8 weeks after the onset of symptoms, according to a WHO report (WHO, 2020).

The scientific literature emphasizes the fact that, unlike previous crises, the COVID-19 crisis has many dimensions. In order to limit the spread of the pandemic, the governments of countries decided to confine millions of people to their homes, which turned out to be an effective way to slow down the increase in new infections, but it brought significant economic costs, such as the collapse of many enterprises or the depletion of a large part of societies destitute. Research has shown that short-term economic losses were greater in countries with fewer fiscal stimuli and with more limited use of monetary policy tools (Deb et al., 2020). In the corporate sector, small enterprises are in the most difficult situation, due to their limited cash resources, they have little chance of waiting out the hard time of the crisis. In the US, small businesses employ nearly $50 \%$ of all employees, and due to the coronavirus, $43 \%$ of small businesses have been shut down in the retail sector, laying off around $40 \%$ of employees. In companies dealing with In gastronomy or tourism, revenues have dropped to almost zero, which, combined with the long duration of the crisis, means that many of them may not reopen (Bartik et al., 2020).

In order to limit the economic consequences caused by the crisis, the need for easy and cheap access to advanced technologies by small enterprises is emphasized. Until now, a significant percentage of enterprises claimed that many technologies are too advanced to be used, but the crisis situation means that the use of many technological solutions may be a necessary condition for the development and even survival of enterprises. The most important of modern solutions are crowdfunding platforms, creating marketing innovations using social media, commercializing ideas for entrepreneurship or using visual analysis technology and big data analysis (Akpan et al., 2020). In the context of the economy as a whole, the literature clearly states that stable and decisive leadership and the implementation of immediate remedial measures are now needed in those sectors of the economy that have been most affected and require recovery as soon as possible. It is also necessary to support entrepreneurship, especially that based on solid and sustainable business models. Social support cannot be ignored either, as it is estimated that during the pandemic the number of calls to the hotline dealing with domestic violence increased by $25 \%$ (Nicola et al., 2020).

Among the employees, people who were not employed under a contract of employment, but earned their earnings under civil law contracts or in other informal ways, are in a particularly difficult situation. However, even during the recession, the re-employment rates of the temporary unemployed are higher than they were during previous crises. This fact is used in more optimistic forecasts of the effects of the current crisis. They assume that most of the unemployment caused by the COVID-19 crisis will be temporary, not long- 
term, as many studies report. Researchers also predict that even assuming that job vacancy rates will return to pre-recession levels in two years, unemployment rates should decline sharply (Gallant et al., 2020).

However, forecasts were also made of how much the suicide rate may increase in the world, almost 9,000 additional people may take their lives due to unemployment, while loneliness may result in up to 40.7 thousand additional suicides, which in total gives the number of nearly 50 thousand additional suicides (Weems et al., 2020). The scientific literature also touches on the problem of digital exclusion, which is of particular importance in the context of remote work or distance learning. The problem of digital exclusion is not only the lack of access to a stable and fast Internet, but also due to the lack of knowledge of the English language, lack of sufficient computer equipment such as a laptop or camera, and the lack of sufficient skills to use modern technologies fluently. Only in Poland, due to infrastructural shortages, approximately 2.5 million Poles could not work remotely or take part in e-learning. This indicator does not take into account the digital divide related to poverty or the lack of skills. It is emphasized that in order to solve this problem, systemic solutions are important, because the market is not able to do it effectively, while in the case of further expansion of remote work, the inability to perform it by many people may result in job cuts, impoverishment of the society and deepening of digital exclusion (Kuc-Czarnecka, 2020).

It has also been observed that epidemics affect societies by changing the way they organize, people's lifestyles, the way people think and make decisions. The crisis caused by the COVID-19 virus has so far destroyed long-standing institutions, transformed global supply chains, and changed the flows of knowledge and capital between countries (Zahra, 2020).

The crisis caused by the spread of the COVID-19 virus also triggered the mass spread of fake news. Many of them did not meet the standard criteria for describing fake news because they came from sources generally considered credible, and the main objection to them was that the information disseminated was imprecise, prompting people to draw hasty and false conclusions (Orso et al., 2020). The main reason for spreading fake news on pandemic-related topics is altruism, people want to share information that can help their loved ones through social media. However, researchers also mention other factors such as: ignorance, unawareness, peer pressure or seeking attention that affect the popularity of sharing false information (Apuke \& Omar, 2020).

\section{MATERIAL AND METHODS}

Preliminary analysis of pandemic data in individual EU countries and in the USA is possible thanks to the availability of detailed data on COVID-19 by the European Center for Disease Prevention and Control. ECDC information has allowed the creation of a panel-type database (data collected in a group of people at various times - over time). The collected data are quantitative data because they contain variables relating to the number of infections, deaths, and active cases of coronavirus. The quantitative method was used to describe the state of COVID-19 incidence and the response of selected areas of the economy to the pandemic. Quantitative data have been processed in order to obtain interesting conclusions on the effectiveness of some methods of fighting the pandemic and the economic crisis.

The desk research method was also used to analyze the materials related to the studied phenomena. The literature was reviewed presenting the available data. The 
case study method was used to show the various actions taken by governments in times of crisis and pandemic.

\section{RESULTS}

\section{The course of the epidemic in individual countries}

The first cases of coronavirus in Europe were detected in France on January 24 (Spiteri et al., 2020). Since then, the virus has quickly spread to all European countries, leading to more than a million infected people across the continent.

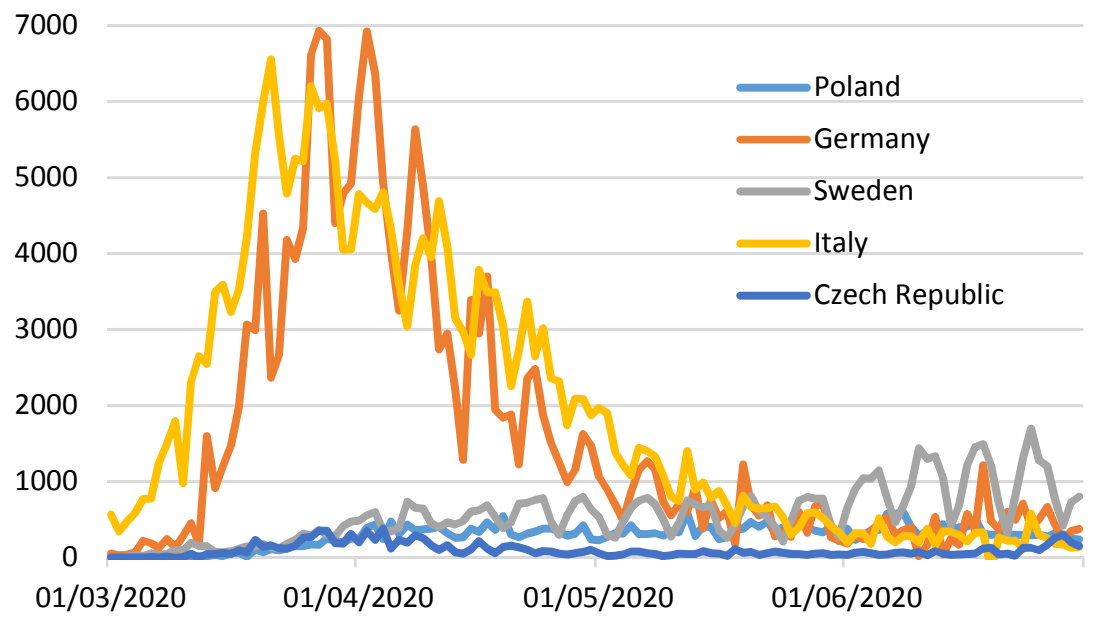

Figure 1. The number of daily cases of COVID-19 infections diagnosed in selected EU connections during the period: 01.03.2020- 27.06.2020 Source: Our World in Data (2020).

As it results from Figure 1, the course of the COVID-19 epidemic and its intensity varied in Europe depending on the country studied and the period adopted. The curve illustrating the number of daily occurrences in Italy in the period March-April is characterized by an upward trend, with slight decreases. After reaching the highest daily number of cases, a downward trend is observed, from May to the end of June the curve gradually flattens. Similarly behaves the curve illustrating the number of daily cases for Germany, which, however, reaches the highest daily number of cases a little later. A slightly different course of the COVID-19 epidemic can be observed in the other countries studied. According to Figure 1, the daily increase in incidence in Sweden, Poland and the Czech Republic in March-June does not exceed 1,000 people. The curve showing the number of new COVID-19 infections in the Czech Republic takes on a flattened form, with slight deviations at the beginning of April. More daily cases were recorded in Poland (which is also associated with a three times larger population), for which the daily infection curve is also flattened in March-June. In Sweden, the number of new infections is steadily increasing over the period considered, with a clear increase in the infected population since June. 


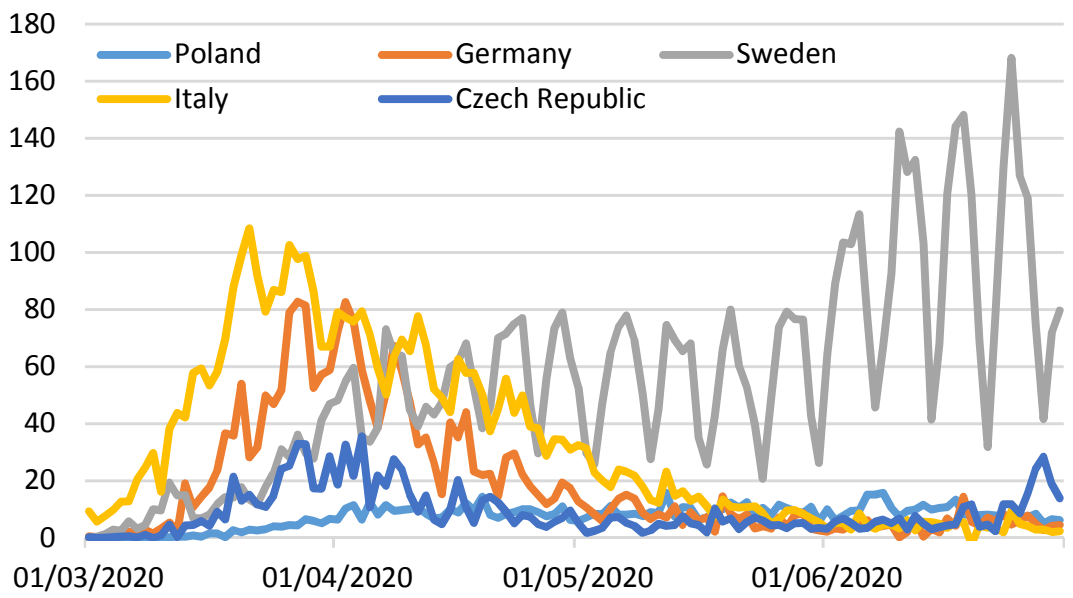

Figure 2. The number of daily cases of COVID-19 infections diagnosed per million inhabitants in selected EU countries during the period: 01.03.2020- 27.06.2020 Source: Our World in Data (2020).

When comparing the number of COVID-19 infections in different countries, it is important to indicate the population size of each of them, so that the results give a reliable picture of the scale of the epidemic in a given country. Figure 2 uses the COVID-19 infected rate indicator in relation to the size of the population of selected countries. According to the Chart, the most dramatic epidemic was observed in March-April in Italy and Germany. In Italy, at the peak of the epidemic, there were just over 100 new cases per million inhabitants per day. The data presented in Figure 2 shows that in the Czech Republic and Poland the number of infected for the total population remains low, while in the case of Sweden the percentage of infected in the population is characterized by numerous deviations from April to early June, and then rapidly increases, at its peak, assuming the value of nearly 300 infected per million inhabitants.

The study also used data on the daily number of deaths due to COVID-19 infection in selected European Union countries. According to Figure 3, the highest number of daily deaths was recorded in Italy in March-May, with the highest number of almost 1000 deaths per day. The curve showing this value for Italy grew rapidly from March to April, after reaching the highest value shows a gradual downward trend.

More detailed information on mortality in selected European Union countries is provided by the indicator of the number of daily deaths compared to the size of the population (per million inhabitants). As shown in Figure 4, the daily mortality resulting from COVID-19 in the Italian population at the peak of the pandemic is 15 people per million inhabitants. Only Sweden shows a higher value among the countries surveyed, reaching 18 cases per million inhabitants a day. 


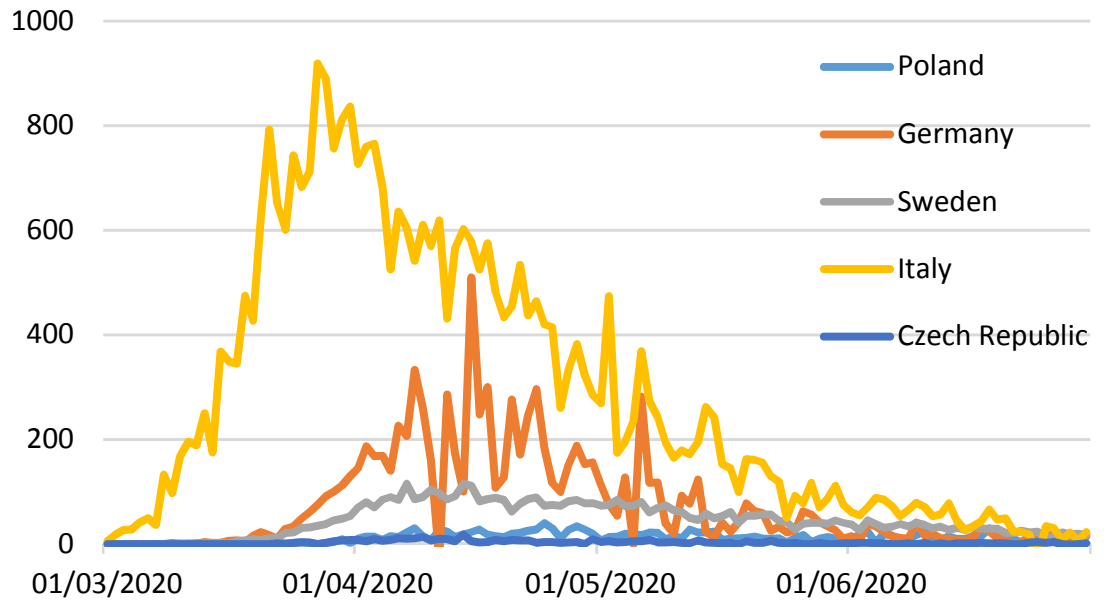

Figure 3. Number of daily deaths due to COVID-19 infection in selected EU countries during the period: 01.03.2020- 27.06.2020 Source: Our World in Data (2020).

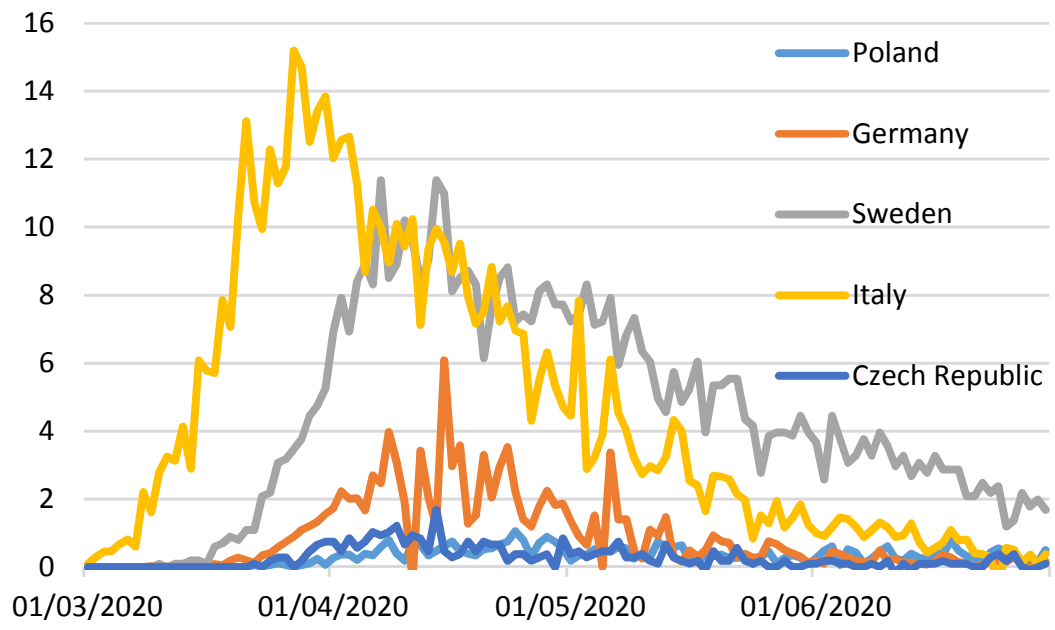

Figure 4. Number of daily deaths due to COVID-19 infection per million inhabitants in selected EU countries during the period: 01.03.2020- 27.06.2020 Source: Our World in Data (2020).

\section{Strategies for managing the epidemic and economic crisis by selected European Union countries}

In the face of the dynamically developing situation related to the spread of COVID-19 and the following economic crisis, governments of many countries had to develop economic plans.

In Poland, legislative solutions regarding economic assistance during the pandemic were called the "anti-crisis shield", which - adopted in a hurry, was subject to several 
amendments. The shield's solutions include state aid in the form of wage subsidies for employees, lifting restrictions on employment for a specified period, postponing the date of payment of ZUS contributions. Subsidies to loans, which are forced by the crisis, entrepreneurs operating in the area of agricultural production, which, in addition to the crisis caused by COVID-19, will also face the effects of drought (Bartosiewicz, 2020) are also a proposed solution. In the anti-crisis shield, the government also proposes to protect Polish enterprises against hostile foreign acquisitions, which will be controlled, among others by the President of UOKiK (Ministry of Development, 2020). For local governments that incurred significant costs associated with adapting the health service to fight a pandemic, the provisions of the anti-crisis shield allow, among others relax debt rules, the possibility of shifting some budget items. Interesting solutions have been introduced in regulations strictly regulating the employment relationship, e.g. enabling the reduction of the employee's working time or extending the employee to economic downtime in the event of a significant increase in the employer's pay load, or temporary suspension of the obligation to collect overdue leaves until 30 September 2020 (Kulpa \& Białecka, 2020). This is a solution that gives a bit of an advantage to the employer, who, due to the crisis caused by the coronavirus, sometimes had to completely suspend his activity. However, this raises doubts about the position of the employee in this situation, to what extent such solutions do not violate the rights of the employee. According to the latest data, less than half of the companies benefited from the assistance offered under the shield. There are many voices suggesting that a tool to stimulate demand would be lifting the trade ban on Sunday. In addition to the hotel and catering industry, which is most often mentioned, the arts industry has suffered as much as a pandemic, which even in the current - fourth stage of defrosting the economy has little chance of returning, because the requirement to fill the rooms in $50 \%$ causes unprofitable opening of the theatre or cinema (Szymański, 2020).

Similar solutions to Polish ones were introduced in Italy - the focus was on transferring funds to companies and employees. As it is a country that derives huge profits from tourism, the government has supported this sector with monetary compensation for losses suffered during the epidemic. As in Poland, tax payments have been deferred in Italy. An innovative solution is the introduction of a voucher for a childminder in the event that an employee cannot take a longer holiday - this seems to be a sensible solution from the point of view of the necessity of employees to work and providing care for children in the event of school closure, at the same time creating new jobs for childminders (Rosińska, 2020).

German solutions aimed at combating the economic crisis are criticized for insufficient assistance to micro enterprises and offering assistance only to the largest companies. On the other hand, Germany was one of the few who decided to cover the costs generated by the coronavirus from budget surpluses from previous years, which indicates a wise, responsible austerity policy (Siemionczyk, 2020).

It is also worth analyzing economic solutions in response to the crisis caused by the coronavirus also in Sweden, which used a completely different tactic to fight the disease than other European Union countries and did not block social and economic life. Economic data indicate that in the first quarter of 2020 the Swedish economy was doing much better than other European Union countries, recording a 0.5\% increase in GDP compared to the first quarter of 2019. For comparison: in Italy, the GDP decline in the first quarter of this year amounted to $4.7 \%$, in Spain 5.2\%, in France 5.8\% However, after two months of the epi- 
demic, according to the Swedish Ministry of Finance, in 2020 Sweden's GDP will shrink by as much as $7 \%$, and around $40 \%$ of companies will declare bankruptcy (Wolska, 2020). The Swedish government has proposed to keep the reference zero interest rate, which it considers an effective measure to stimulate demand. However, the future effects of the Swedish government's liberal policy are puzzling. The high number of COVID-19 infections in Sweden and the number of deaths suggest that this country - already struggling with the demographic crisis - may have even greater problems in the future after coronavirus (Rząsa, 2020).

\section{Impact of the crisis on macroeconomic variables}

In order to verify the impact of the crisis on the economy and its response to solutions in the area of economy proposed by governments, it is necessary to analyze the variability of such indicators as e.g. the unemployment rate, the volume of industrial production, the development of business activity in the area of retail trade and the financial situation of consumers.

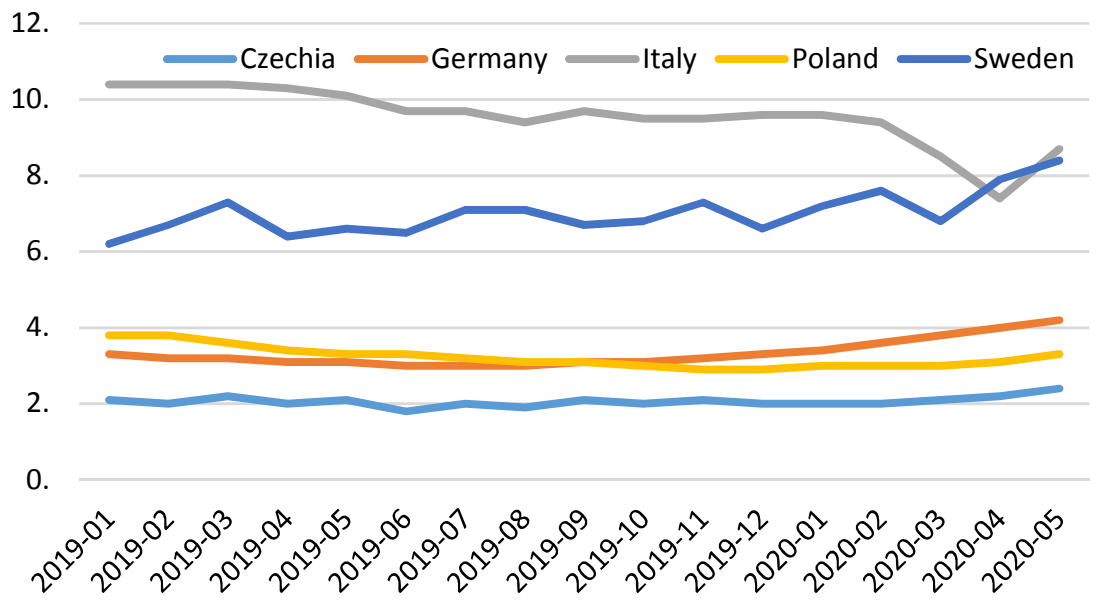

Figure 5. Unemployment rate from January 2019 to April 2020 Source: Eurostat (2020a).

As it results from the data presented in Figure 5 among the EU countries surveyed, in January 2019-April 2020 the highest unemployment rate is recorded by Italy (at the highest point it is about 11\%). Despite the dramatic course of the coronavirus pandemic in Italy, the unemployment rate dropped significantly at the beginning of 2020, in April 2020 it amounted to 6\% (against the previous 10\% in December 2019). This is due to the fact that the decrease in the unemployment rate is associated with a decrease in the number of people seeking employment, which was caused by social unrest related to the pandemic, quarantine coverage, as well as waiting for the resumption of production in the workplace (Żuławiński, 2020). As the data from Figure 5 show, in Poland, Germany or the Czech Republic there is no clear impact of the COVID-19 crisis on the employment rate, in each of these countries it takes the form of a flattened curve, with slight deviations. The increase in the unemployment rate in Sweden (which has introduced the least restrictions on socio-economic life) can be explained by a high dependence on exports, representing $50 \%$ of GDP (Sikorski, 2020). 


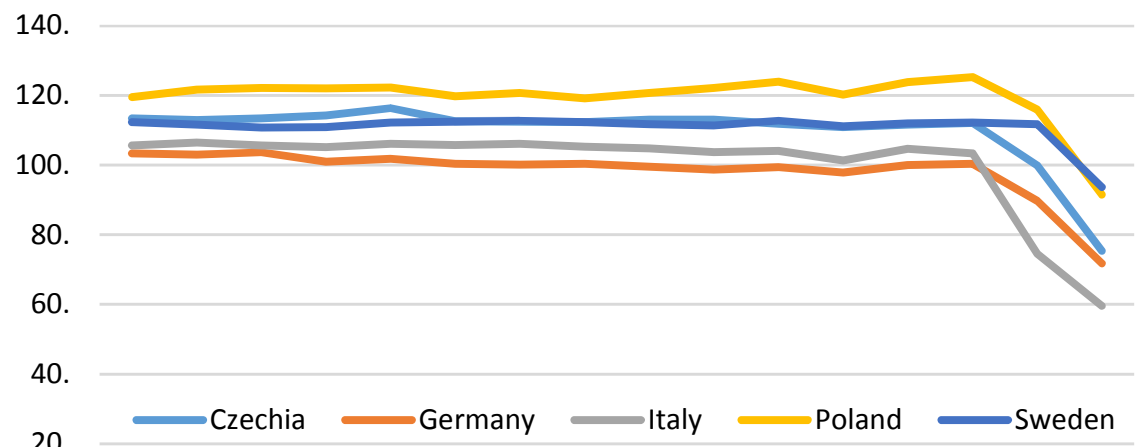

0.

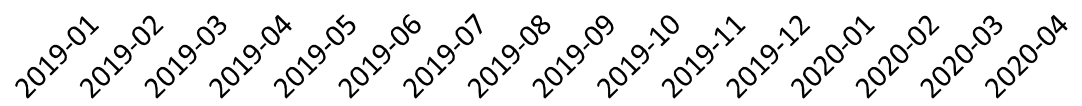

Figure 6. Production in industry from January 2019 to April 2020 Source: Eurostat (2020b).

The graph above shows production in industry, where the base value for 100 was 2015. As shown in Figure 6, in February 2020-April 2020 the curves showing the volume of production in industry show a downward trend for each of the five selected European Union countries. The largest decrease in production in industry is observed in Italy, where in the period from February to April a decrease of nearly $40 \%$ was noted, which is related to the fact that Italy was the region most affected by the COVID-19 pandemic in Europe. The downward trend in industrial production in Germany is confirmed by data from the Federal Statistical Office, according to which in March 2020 industrial production in Germany fell by over $9 \%$, which was associated with a decrease in domestic and international demand. The drop in production in industry in the Czech Republic by more than $30 \%$ is, in turn, caused by a lack of supply from China and the difficult situation in Italy, which is an important trading partner for this country.

Chart 7 illustrates the development of business activity in the area of retail sales in the period January 2019 - May 2020. Among all the compiled countries, the effects of the crisis are most visible in Poland, where this indicator decreased by nearly $120 \%$ compared to the period before the first detected case of infection in this country. An equally severe decline was observed in Italy, while the smallest reduction was recorded in the Czech Republic.

The last of the indicators presented is the financial position of consumers. As in the case of the indicator on retail sales, Poland turned out to be the most affected country, where the situation of consumers in relation to the period before the pandemic deteriorated by more than $150 \%$. However, consumers in Sweden and Germany suffered the least from the effects of coronavirus. 


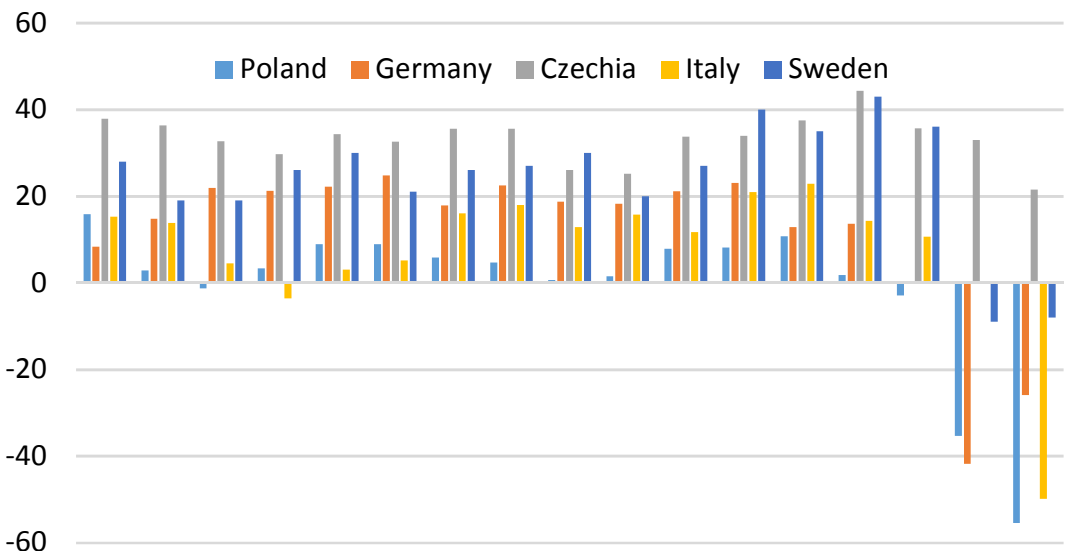

$-60$

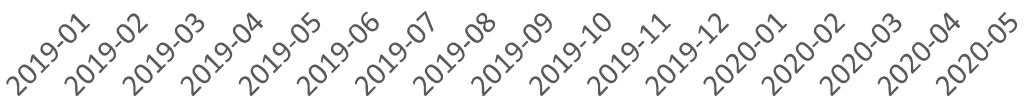

Figure 7. Business activity development - retail sales from January 2019 to May 2020 Source: Eurostat (2020c).

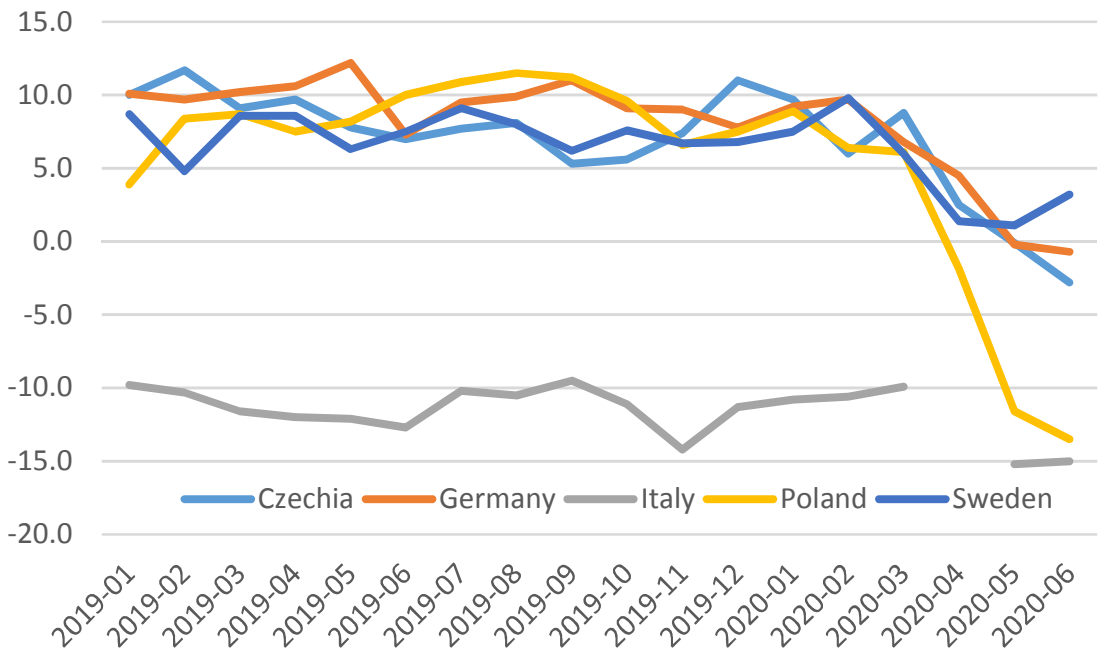

Figure 8. Financial situation - consumers from January 2019 to June 2020 Source: Eurostat (2020c).

\section{CONCLUSIONS}

The effects of the COVID-19 pandemic are visible not only on the plane of the epidemic, but also on the economic plane. In a report on selected methods of fighting the European Union against the epidemic and summoned by it against the Economic Commission. 
In the first part of the article described the scale of the epidemic in Italy, Poland, Sweden, the Czech Republic and Germany. The inventory, the liberal approach of Swedish epidemiologists translated into a high percentage of those infected in groups, and despite the need to limit the scope of measures, Sweden may use declines in GDP, like the other countries studied.

COVID-19 should be used with caution and the unemployment rate should be assessed, the number of indicators for the countries studied in the period January - May 2020 should be taken into account, should be taken into account. with the suspension of many labour services.

The study showed that a decrease in production in the analysis was observed in Italy where in the period from February to April a decrease of nearly $40 \%$ was recorded. Lists of other surveyed countries - the Czech Republic, Germany, Sweden and Poland report clear declines in production by several dozen percent in the group in the period under review.

The crisis affecting the decline in activity in the analysis of retail sales in the period January 2019 - May 2020. From among all sets of markets in terms of activities visible in Poland, where this indicator decreased by nearly $120 \%$ depending on the period before detecting the risk of accidental infection in this country.

Further research recommends extending the research carried out to include the longterm effects of the policies applied in various countries, as well as extending the research to other countries, in particular the USA and China.

\section{REFERENCES}

Akpan, I.J., Soopramanien, D., \& Kwak, D.H. (2020). Cutting-edge technologies for small business and innovation in the era of COVID-19 global health pandemic. Journal of Small Business \& Entrepreneurship, 32(6), 1-11.

Alesina, A., de Broeck, Prati, A., \& Tabellini, G. (1992). Default risk on government debt in OECD Countries. Economic Policy: A European Forum, 7(15), 427-463.

Apuke, O.D., \& Omar, B. (2020). Fake news and COVID-19: modelling the predictors of fake news sharing among social media users. Telematics and Informatics, 56.

Bartik, A. W., Bertrand, M., Cullen, Z., Glaeser, E.L., Luca, M., \& Stanton, C. (2020). The impact of COVID-19 on small business outcomes and expectations. Proceedings of the National Academy of Sciences, 117(30), 17656-17666.

Bartosiewicz, A. (2020). Tarcza antykryzysowa. Szczególne rozwiqzania w prawie podatkowym, rozliczeniach ZUS i wybranych aseptkach prawa pracy zwiqzane z COVID-19. Wolters Kluwer.

Deb, P., Furceri, D., Ostry, J.D., \& Tawk, N. (2020). The economic effects of Covid-19 containment measures. IMF Working Papers, 20(158), 4-44.

Eurostat (2020a). Unemployment - monthly data. Retrieved June 21,2020 from https://ec.europa.eu/eurostat/databrowser/view/une_rt_m/default/table?lang=en\&fbclid=IwAR3LLQ75dtBSHleNZI-pN5gxDu-S-UfTtb_hN7W7AiYH_d-XAczQkjKF8-I

Eurostat (2020b). Production in industry - monthly data. Retrieved June 20, 2020 from https://ec.europa.eu/eurostat/web/products-datasets/-

/sts_inpr_m?fbclid=IwAROht|xO51XKjyLp6ICYw50z7MMQWVOEQF6PJjo7uyQqGCEKigkEUuGB8bo

Eurostat (2020c). Business and Consumer Surveys. Retrieved June 20, 2020 from https://ec.europa.eu/eurostat/web/euro-indicators/business-and-consumer-surveys?fbclid=IwAR3DnsJR-NgfFhILIlm-QUgo4w9MMpUd3SUwB88k2bQxbfDH_xioXBGjWs 
Gallant, J., Kroft, K., Lange, F., \& Notowidigdo, M.J. (2020). Temporary Unemployment and Labor Market Dynamics During the COVID-19 Recession. Brookings Papers of Economic Activity, 141, 1-45.

Kuc-Czarnecka, M. (2020). COVID-19 and digital deprivation in Poland. Oeconomia Copernicana, 11, 415-431.

Kulpa, R., Białecka, A. (2020). Możliwości uelastycznienia czasu pracy. Retrieved on June 10, 2020 from https://home.kpmg/pl/pl/blogs/home/posts/2020/04/.

Li, G., \& De Clercq, E. (2020). Therapeutic options for the 2019 novel coronavirus (2019-nCoV), Nature Reviews Drug Discovery, 19(3), 149-150.

Ministry of Development (2020). Tarcza antykryzysowa. Retrieved June 10,2020 from https://www.gov.pl/web/rozwoj-praca-technologia/tarcza-antykryzysowa?fbclid=IwAROTDO2fXZ8leiUMMQxSNXrwbpQ_JXK5yLh32PXCZIIJkCkVoPhHzJ2f9g

Nicola, M., Alsafi, Z., Sohrabi, C., Kerwan, A., Al-Jabir, A., losifidis, C., \& Agha, R. (2020). The socioeconomic implications of the coronavirus pandemic (COVID-19): A review. International Journal of Surgery, 78, 185-193.

Orso, D., Federici, N., Copetti, R., Vetrugno, L., \& Bove, T. (2020). Infodemic and the spread of fake news in the COVID-19-era. European Journal of Emergency Medicine, 10(4). Retrieved June 26, 2020 from https://www.ncbi.nlm.nih.gov/pmc/articles/PMC7202120/

Our World in Data (2020). Coronavirus Pandemic Data Explorer. Retrieved June 20,2020 from https://ourworldindata.org/coronavirus-data-explorer?zoomToSelection=true\&time=2020-0301..latest\&country=IND USA GBR CAN DEU FRA\&region=World\&casesMetric=true\&interval=smoothed\&perCapita=true\&smoothing=7\&pickerMetric=total_cases\&pickerSort=desc\&fbclid=IwAROFukVVtQnQjbVRTOTOPx8PUe8B4pP2jrmfLzFFmsTbC2dJkx-RTwFUs8c

Rosińska, M. (2020). Zrozumieć COVID-19. Retrieved on September 14, 2020 from https://informacje.pan.pl/images/2020/opracowanie-covid19-14-09-2020/ZrozumiecCovid19_opracowanie_PAN.pdf

Rząsa, D. (2020). Czy Szwecja zrobiła dobrze nie zamykajqc gospodarki na czas epidemii? Dane na to nie wskazujq, ale dyskusja trwa. Retrieved June 26,2020 from https://300gospodarka.pl/news/szwedzka-strategia-koronawirus-konsekwencje

Siemionczyk, G. (2020). Niemcy w głębokiej recesji, ale jest nadzieja. Retrieved June 13,2020 from https://www.rp.pl/Dane-gospodarcze/305219981-Niemcy-w-glebokiej-recesji-ale-jest-nadzieja.html?fbclid=IwAR0eVx9MKx9go_tf1_XkSfC9nWlePhDd4qpuHho2Las3UMmfgev9LtUgkhg

Sikorski, K. (2020). Szwecja: Nikt już nie umiera od koronawirusa, zakażonych jest mało.Jak Szwedzi to zrobili? Retrieved September 20, 2020 from https://polskatimes.pl/szwecja-nikt-juz-nieumiera-od-koronawirusa-zakazonych-jest-malo-jak-szwedzi-to-zrobili/ar/c1-15182654

Spiteri, G., Fielding, J., Diercke, M., Campese, C., Enouf, V., Gaymard, A., \& Demina, Y. V. (2020). First cases of coronavirus disease 2019 (COVID-19) in the WHO European Region, 24 January to 21 February 2020. Eurosurveillance, 25(9), 1-6.

Szymański, D. (2020). Biznes ma dość „strzałów w kolano”. Bierze sprawy w swoje ręce. Retrieved October 20, 2020 from https://businessinsider.com.pl/firmy/sztab-kryzysowy-w-branzy-gastronomicznej-i-hotelarskiej/lzzmtn6

Wolska, A. (2020). Szwecję czeka recesja, mimo braku lockdownu. Retrieved June 11, 2020 from https://www.euractiv.pl/section/gospodarka/news/koronawirus-szwecja-nie-wprowadzilalockdown-a-i-tak-jej-gospodarka-mocno-ucierpi-epidemiaue/?fbclid=IwAROht|xO51XKjyLp6ICYw50z7MMQWV0EQF6PJjo7uyQqGCEKigkEUuGB8bo

WHO (2020). World Health Statistics 2020. Retrieved June 26,2020 from https://www.who.int/data/gho/whs-2020-visual-summary 
Weems, C.F., Carrion, V.G., Mccurdy, B.H., \& Scozzafava, M.D. (2020). Increased risk of suicide due to economic and social impacts of social distancing measures to address the Covid-19 pandemic: $A$ forecast. Retrieved June 26, 2020 from https://www.researchgate.net/publication/340487993.

Wu, Z., \& McGoogan J.M. (2020). Characteristics of and important lessons from the coronavirus disease 2019 (COVID 19) outbreak in China. Retrieved June 26, 2020 from https://jamanetwork.com/journals/jama/fullarticle/2762130.

Zahra, S.A. (2020). International entrepreneurship in the post Covid world. Journal of World Business, 56(1).

Żuławiński, M. (2020). Stopa bezrobocia w marcu spadła. Kryzys dopiero przed nami. Retrieved on June 15, 2020 from https://www.bankier.pl/wiadomosc/Stopa-bezrobocia-w-marcu-spadla-Kryzysdopiero-przed-nami-7869928.html?fbclid=IwAR12sSvKMRqtaw4Tq3S96y7o2GutsDzPWp_BhiWStOmbQAZOuJKxzErBdhw.

\section{Authors}

The contribution share of authors is equal and amounted to $50 \%$ for each of them.

\section{Martyna Żak}

Bachelor in Economics. Currently Master Student of Economics at Cracow University of Economics (Poland).

Correspondence to: zak.martyna.m@gmail.com

ORCID (1) http://orcid.org/0000-0001-8351-8646

\section{Jakub Garncarz}

Bachelor in Economics. Currently Master Student of Economics at Cracow University of Economics (Poland).

Correspondence to: garncarz.jakub@gmail.com

ORCID (i) http://orcid.org/0000-0003-0166-9403

\section{Copyright and License}

This article is published under the terms of the Creative Commons

Attribution - NoDerivs (CC BY-ND 4.0) License

http://creativecommons.org/licenses/by-nd/4.0/

Published by Cracow University of Economics - Krakow, Poland 